\title{
pH, Total Bacteria and Total Fungi Litter Fermentation at Different Ripening Durations
}

\author{
C. S. Utama, B. Sulistiyanto, and O. Barus \\ Department of Animal Science, Faculty of Animal and Agricultural Sciences, \\ Universitas Diponegoro. \\ Jl. Prof. H. Soedarto, S.H, Semarang City, Central Java 50275, Indonesia \\ Corresponding Author : cahyasetyautama@gmail.com
}

\begin{abstract}
The study aimed to examine the effect of fermentation time on $\mathrm{pH}$ levels, total bacteria, and total fungi in fermented chicken litter. The research was carried out by collecting various chicken litters from 16 closed-house cages in Semarang City, Demak Regency, and Kendal Regency, then combined and fermented. The study used a completely randomized design with 4 treatments and 4 replications, the treatments were $\mathrm{T} 0=$ litter ripening 0 weeks; T1 $=3$ weeks litter ripening; T2 $=6$ weeks litter ripening; T3 $=9$ weeks litter ripening. Parameters observed were $\mathrm{pH}$ value, total bacteria, and total fungus in broiler chicken litter. The results showed that there was a significant effect $(\mathrm{P}<0.05)$ between ripening duration on the $\mathrm{pH}$ value and the total bacteria litter of fermented broiler chickens. The longer the ripening duration, the lower the $\mathrm{pH}$ value, because the longer fermentation process produces more organic acids. The results of the total bacteria count showed that the best treatment was T2 treatment with the number of bacteria as much as $8.12 \times 10^{7} \log \mathrm{CFU} / \mathrm{g}$. Meanwhile, the total fungus had no significant effect $(\mathrm{P}>0.05)$ in all treatments. The study concluded that the best-fermented chicken litter was at 6 weeks of ripening, produced a total of $0.25 \times 10^{3} \mathrm{CFU} / \mathrm{g}$ bacteria and fungi and is indicated not to be pathogenic bacteria and fungi.
\end{abstract}

Key words: litter, ph, total bacteria, total fungi

\section{INTRODUCTION}

Broiler farming is one of the livestock industries that is growing continuously from a small scale to a commercial scale with rapid progress (Istiqamah et al., 2019). This is due to the increasing demand for chicken meat products mainly caused by increasing population, community income, and public awareness for an adequate nutritional intake. Currently, the broiler chicken industry is using a maintenance system by applying technology known as a closed house maintenance system that can minimize the adverse effects of the environment and promote chicken productivity (Prihandanu et al., 2015). Maintenance of broiler chickens with an open or closed system requires good litter management for optimal growth and development of chickens and reducing the impact of economic losses (Purwono, 2018). The litter material generally used is rice husk, which functions as a chicken bed, provides warmth, reduces humidity on the floor of the cage, and absorbs chicken manure (manure) so that the ammonia level of the cage can be controlled (Anwar et al., 2014). At the end of maintenance, the litter will consist of a mixture of husks and broiler manure.

Chicken litter at the end of maintenance is generally used as fertilizer. If further processing is carried out, chicken litter has the potential to be used as feed for ruminants (Sariri and Harinta, 2018). This is because the manure content in the chicken litter has good protein and TDN levels. The nutritional content of broiler litter is $25-50 \%$ crude protein and 55-60\% TDN (Rahimi et al., 2018). Broiler chicken manure contains $2.2 \%$ Nitrogen, $1.41 \%$ Phosphorus, and $1.52 \%$ Potassium (Amanullah et al., 2010). The content of the manure varies depending on how it is processed and the conditions of the manure. Minerals such as calcium $(\mathrm{Ca})$, magnesium $(\mathrm{Mg})$, iron $(\mathrm{Fe})$, sulfur $(\mathrm{S})$, manganese $(\mathrm{Mn})$, copper $(\mathrm{Cu})$, zinc $(\mathrm{Zn})$, and chlorine $(\mathrm{Cl})$ are also found in broiler manure. The minerals contained in the manure mostly come from drinking water, feed, and medicines given to broiler chickens (Yanuartono et al., 2018). The content in chicken manure is needed by ruminants for growth and production. However, in the chicken litter, there is rice husk, with crude fiber content reaching 53.63\% (Amrullah et al., 2019). The high crude fiber content affects the organic matter content of rice husks so that it can reduce the level of digestibility of the material when consumed by ruminants (Wijayanti et al., 2012). Pathogenic bacteria and fungi are also found in the chicken litter because of the excreta that allow bacteria and fungi to grow. Broiler chicken feed is high in protein, feed nutrients that are not absorbed by the body will be removed along with other substances 
that are not absorbed, through excreta consisting of feces and urine (Marang et al., 2019). One alternative to reduce levels of pathogenic bacteria and fungi in the chicken litter is to use fermentation technology.

Fermentation is a biochemical process that involves microorganisms and occurs under anaerobic conditions. In fermentation, there is a process of energy formation through organic compounds that occurs due to a combination of the right organic substrate with microorganisms that cause fermentation (Hastuti et al., 2011). Fermentation of feed processing can increase the efficiency of feed use because the final product of fermentation contains simpler compounds, fermentation can also reduce and eliminate the activity of microorganisms and toxic substances contained in an ingredient (Pamungkas, 2011). Feed ingredients that are high in fiber content can be converted into more digestible by fermentation with cellulolytic organisms that can digest cellulose or components that make up cell walls (Munira and Tasse, 2016). The fermentation process can be done by adding a starter (microorganism) that is suitable for the substrate and the purpose of fermentation. Fermentation of feed processing has advantages, namely, it does not require specific equipment, costs less, does not cause harmful impacts and the implementation process is easy to do (Wikanastri et al., 2012).

This study aimed to examine the effect of the ripening duration of fermented chicken litter on the $\mathrm{pH}$ value, total bacteria, and total fungi. This study was useful to obtain information on the effect of different ripening durations on $\mathrm{pH}$ values, total bacteria, and total fungi in fermented chicken litter. The results of fermented chicken litter are expected to reduce the negative impact caused by chicken litter for humans and the environment if it is not used.

\section{MATERIALS AND METHODS}

The materials used in the study were broiler chicken litter, molasses, urea, salt, mineral mix, starter mix culture, and distilled water while the tools used were tarpaulin, zip plastic, analytical scales, trays, blender, fermented plastic, glass, rope, $\mathrm{pH}$ meter, shovel. The method used in this research includes the preparation, research implementation, and analysis stage.

\section{Preparation Stage}

The initial stage of the study was carried out by collecting broiler chicken litter from 16 cages with an open maintenance system (open house) and a closed house system (closed house) partner PT. Cemerlang Unggas Lestari located in Semarang City, Kendal Regency and Demak Regency.

\section{Research Implementation}

Litter was weighed $1 \mathrm{~kg}$ from each cage. The litter that has been weighed is then mixed until homogeneous using a tarpaulin base and a shovel. Litter that has been mixed, then divided into 16 parts and put into plastic. Then, 60 grams of starter mix culture were added, 60 grams of the mineral mix, 60 grams of salt, 60 grams of urea, and $60 \mathrm{ml}$ of molasses mixed with $100 \mathrm{ml}$ of water, all ingredients were mixed until homogeneous. Homogeneous litter was put into plastic and fermented anaerobically. Plastics were labeled and data were collected according to treatment (T0, T1, T2, and T3).

\section{Analysis Stage}

The process of testing the $\mathrm{pH}$ is done by turning on the tool and $\mathrm{pH}$ meter calibrated with buffer solution $\mathrm{pH} 7$. The sample was weighed as much as $\mathbf{5}$ grams put in a glass, then add distilled water as much as 5 grams to cups. The material is stirred until homogeneous, after 2 hours of measuring the $\mathrm{pH}$ of the material with the electrode is dipped in the sample and the value of $\mathrm{pH}$ can be read on the scale indicated by the pointer. Measurement of total bacteria and total fungi by using the method of Total Plate Count. The calculation of the total bacteria was done by counting the number of colonies of bacteria and the number of mushrooms that are formed on the Petri film, according to the procedure by Wibowo et al. (2015).

\section{Research Design}

This research used Complete Random Design (CRD) pattern in unidirectional with 4 treatments and 4 repeats. The treatment is long fermented (fermentation) chicken litter.

T0: Fermented chicken litter, 0 week ripening duration

T1: Fermented chicken litter, 3 weeks ripening duration

T2: Fermented chicken litter, 6 weeks ripening duration

T3: Fermented chicken litter, 9 weeks ripening duration

\section{Data Analysis}

The data obtained were analyzed using the Analysis of Variance (ANOVA) test to check the diversity of the data and if there was a 
significant effect, it was continued with the Duncan's Multiple Range Test (DMRT) test with a 5\% confidence level.

\section{RESULTS AND DISCUSSION}

\section{PH value}

Based on the results of the study in Table 1 shows that there is a significant effect $(\mathrm{P}<0.05)$ of different ripening duration treatments on the $\mathrm{pH}$ value of fermented chicken litter.

Based on the results of the measurement of $\mathrm{pH}$ values, it was shown that the ripening duration of treatment $\mathrm{T} 0, \mathrm{~T} 1, \mathrm{~T} 2$, and $\mathrm{T} 3$ was significantly different $(\mathrm{P}<0.05)$ on the $\mathrm{pH}$ value of fermented chicken litter. The lowest average $\mathrm{pH}$ value was in treatment T3 (7.35) while the highest average $\mathrm{pH}$ value was in treatment $\mathrm{T} 0$ (8.63). The lower $\mathrm{pH}$ value at $\mathrm{T} 3$ indicates a better fermentation process compared to other treatments because it produces more organic acids. The results of measuring $\mathrm{pH}$ values in this study are almost the same as those of Marang et al. (2019) stated that the $\mathrm{pH}$ of broiler litter ranges from 7.35 to 8.40 . The difference in $\mathrm{pH}$ values in each treatment was caused by differences in the products produced during the fermentation process in each treatment. The longer the ripening duration, the longer the time for fermentation, so the higher the acid produced from the fermentation process. Nasrun et al. (2015) stated that the decrease in $\mathrm{pH}$ value in the fermentation process could be caused by the activity of microorganisms that produce organic acids such as lactic acid, acetic acid, propionic acid, butyric acid, malic acid, tartaric acid, citric acid and also produce ethanol as primary metabolites during the fermentation process. The higher bacterial activity also produces more lactic acid, so the $\mathrm{pH}$ value decreases. Ningsih et al. (2018) stated that the decreasing $\mathrm{pH}$ value could be caused by the activity of lactic acid bacteria which produce more lactic acid during the fermentation process.

Table 1. $\mathrm{pH}$ value of fermented chicken litter on different lengths of ripening

\begin{tabular}{ccccc}
\hline \multirow{2}{*}{ Replication } & \multicolumn{4}{c}{ Length of ripening } \\
\cline { 2 - 5 } & T0 & T1 & T2 & T3 \\
\hline 1 & 8.68 & 7.89 & 7.76 & 7.38 \\
2 & 8.75 & 8.06 & 7.65 & 7.31 \\
3 & 8.66 & 8.39 & 7.57 & 7.26 \\
4 & 8.44 & 7.93 & 7.63 & 7.45 \\
\hline Average & $8,63^{\mathrm{a}} \pm 0,13$ & $8.07^{\mathrm{b}} \pm 0,22$ & $7.65^{\mathrm{c}} \pm 0,07$ & $7.35^{\mathrm{d}} \pm 0,08$ \\
\hline
\end{tabular}

Description: different superscripts on the same line showed significant differences $(\mathrm{P}<0.05)$.

The difference in $\mathrm{pH}$ values in each treatment $\mathrm{T} 0, \mathrm{~T} 1, \mathrm{~T} 2$, and $\mathrm{T} 3$ is thought to be because the ripening duration gap between treatments is quite far, namely 3 weeks ( 21 days) so that the production of organic acids produced by the longest ripening treatment will also be higher, and the production of these organic acids will be sequential according to the ripening duration. Qadarullah et al. (2018) stated that the more organic acids produced during the fermentation process, is the result of a lot of bacterial activity, so it can affect the $\mathrm{pH}$ value. However, this assumption is limited until when during fermentation there are still decomposing bacteria and bacteria obtain nutrients from materials such as carbon, nitrogen, organic ions, vitamins, and water for their development. The difference in $\mathrm{pH}$ values in each treatment $\mathrm{T} 0, \mathrm{~T} 1$, $\mathrm{T} 2$, and $\mathrm{T} 3$ can also be caused by differences in water content in each treatment when testing the $\mathrm{pH}$ value. In the T0 treatment the samples were wetter so that the water content was high, the water content decreased with the longer fermentation time. Metasari et al. (2014) stated that the quality of the litter $\mathrm{pH}$ is influenced by the water content of the litter, the higher the litter $\mathrm{pH}$ can be caused by the wetter litter content, so it can increase the $\mathrm{pH}$ value of broiler chicken litter.

\section{Total Bacteria}

Based on the results of the study in Table 2 shows that there is a significant effect $(\mathrm{P}<0.05)$ of different ripening duration treatments on the total bacteria of fermented chicken litter.

Based on the results of the variance test (Table 2), it was shown that the ripening duration had a significant effect $(\mathrm{P}<0.05)$ on the total number of bacteria in the fermented chicken litter. The ripening is done to reduce the total number of bacteria. The total bacteria at T0 was the highest compared to the total bacteria in the $\mathrm{T} 1, \mathrm{~T} 2$, and $\mathrm{T} 3$ treatments. The results of the T0 study were significantly different from $\mathrm{T} 1, \mathrm{~T} 2$, and $\mathrm{T} 3$; $\mathrm{T} 1$ was significantly different from $\mathrm{T} 2$ and $\mathrm{T} 3$; while 
Table 2. Total bacteria of fermented chicken litter on different lengths of ripening

\begin{tabular}{|c|c|c|c|c|}
\hline \multirow{2}{*}{ Replication } & \multicolumn{4}{|c|}{ Length of ripening } \\
\hline & T0 & $\mathrm{T} 1$ & $\mathrm{~T} 2$ & T3 \\
\hline & \multicolumn{4}{|c|}{ - } \\
\hline 1 & 8.40 & 7,95 & 8,04 & 8,20 \\
\hline 2 & 8.41 & 7.78 & 8,11 & 8,04 \\
\hline 3 & 8.38 & 7,85 & 8,11 & 8,00 \\
\hline 4 & 8.55 & 7,90 & 8,20 & 8,15 \\
\hline Average & $8.38^{\mathrm{a}} \pm 0.02$ & $7.87^{\mathrm{c}} \pm 0.07$ & $8.12^{\mathrm{b}} \pm 0.06$ & $8.10^{\mathrm{b}} \pm 0.09$ \\
\hline
\end{tabular}

Description: different superscripts on the same line showed significant differences $(\mathrm{P}<0.05)$.

$\mathrm{T} 2$ was not significantly different from T3. The highest total bacteria was in treatment $\mathrm{T} 0(8.38 \mathrm{x}$ $\left.10^{7} \mathrm{CFU} / \mathrm{g}\right)$.

This can happen because in this treatment there is no fermentation process, so there is no mechanism that kills some of the bacteria present in the chicken litter. Najibulloh et al. (2020) stated that fermenting chicken litter can reduce total bacteria because some of the bacteria in the litter will die due to the heat generated during the fermentation process. Bacteria can also thrive at T0 because the value of the degree of acidity $(\mathrm{pH})$ has not decreased. The T0 treatment had a $\mathrm{pH}$ value that was significantly different from the ripening treatment, at a high $\mathrm{pH}$ it became a potential place for bacteria to grow, thereby increasing the total number of bacteria. Main et al. (2020) stated that $\mathrm{pH}$ levels that have not decreased in the fermentation treatment can be a good place for bacteria to grow and develop.

The T1 treatment had a lower total bacterial value compared to the T0 treatment because when the ripening the fermentation process that produces lactic acid bacteria. Lactic acid bacteria (gram-positive bacteria) that grow will interfere with the presence and reduce the number of gram-negative bacteria. Mukodiningsih et al. (2018) stated that in the fermentation process, increased gram-positive bacteria could reduce the number of gramnegative bacteria. These gram-positive bacteria are lactic acid bacteria that damage the outer membrane of gram-negative bacteria (lipopolysaccharide layer) which is located on the surface of the outer membrane of gram-negative bacteria so that antimicrobials enter the cytoplasmic membrane and inhibit the growth of gram-negative bacteria.

The $\mathrm{T} 2$ and $\mathrm{T} 3$ treatments were not significantly different, but the total number of bacteria in both treatments was higher than in the T1 treatment. This is because the longer the ripening duration, the higher the population of lactic acid bacteria will degrade various types of sugar into lactic acid, thereby increasing the total number of bacteria. Ferdaus et al. (2008) stated that the longer the fermentation time, the more lactic acid bacteria will grow and multiply. The T2 and $\mathrm{T} 3$ treatments did not have a significant effect because the substrate needed by bacteria to grow was not sufficient. After all, it was almost depleted which did not increase the total number of bacteria.

Bacterial growth in each fermentation treatment is influenced by temperature, $\mathrm{pH}$, and nutrients contained in the material. Wulandari et al. (2020) stated that the factors that influence the growth of bacteria are the nutrient content contained in the material which is a source of nutrition for bacterial growth, contamination during sample preparation, $\mathrm{pH}$ value, and temperature of the material. The recommended treatment is at $\mathrm{T} 2$, namely ripening fermented chicken litter for 6 weeks because it provides optimum total bacteria yield compared to other treatments.

\section{Total Fungi}

Ripening Based on the results of the study in Table 3 shows that there is no effect $(\mathrm{P}>0.05)$ of different ripening duration treatments on the total fermented chicken litter fungus.

Table 3. A total of fungi of fermented chicken litter on different length of ripening

\begin{tabular}{cllll}
\hline \multirow{2}{*}{ Replication } & \multicolumn{4}{c}{ Length of Ripening } \\
\cline { 2 - 4 } & T0 & T1 & T2 & T3 \\
\hline 1 & 0 & 0 & 0 & 0 \\
2 & 0 & 0 & 1 & 0 \\
3 & 2 & 0 & 0 & 1 \\
4 & 0 & 0 & 0 & 0 \\
\hline Average & $0.5^{\mathrm{a}}$ & $0^{\mathrm{a}}$ & $0.25^{\mathrm{a}}$ & $0,25^{\mathrm{a}}$ \\
\hline
\end{tabular}

Description : different superscript on the same line showed significant difference $(\mathrm{P}<0.05)$. 
Based on the results of the test of variance (Table 3.) showed that the ripening duration was not significantly different $(\mathrm{P}>0.05)$ from the total number of fermented chicken litter fungi. The low or almost no total number of fungi in the fermented chicken litter is thought to be due to the presence of other microorganisms such as bacteria that live on the material, thus interfering with the presence of fungi. Nurdianto et al. (2015) stated that the non-growth of fungi could be due to the presence of other microorganisms living on the material, thus allowing for competition.

In each treatment $\mathrm{T} 0, \mathrm{~T} 1, \mathrm{~T} 2$, and $\mathrm{T} 3$ there was almost no total number of fungi because at the time of the research the $\mathrm{pH}$ value, the average $\mathrm{pH}$ was in the range of $7-8$ or in the neutral range, while the conditions for fungi to grow optimally were in acidic conditions. until neutral. Dewi et al. (2014) stated that acidity conditions affect the development of fungi, fungi can grow optimally in acidic conditions and have a fairly wide $\mathrm{pH}$ range between 2-8. Factors that affect the total fungus in the chicken litter are temperature, humidity, substrate, and acidity. Prayitno et al. (2014) stated that the fungal growth process is strongly influenced by the available substrate and the $\mathrm{pH}$ conditions of the material. The total number of fungi present can determine the quality of fermented chicken litter. Main et al. (2020) stated that the total mushroom is one of the parameters that determine the good or bad of a product.

\section{CONCLUSION}

The ripening duration of fermented chicken litter affects the $\mathrm{pH}$ value of chicken litter, the longer the ripening duration, the lower the $\mathrm{pH}$ value. The best chicken litter fermentation is at 6 weeks of ripening duration. Produced a total of $8.12 \times 10^{7} \log \mathrm{CFU} / \mathrm{g}$ of bacteria and a total of $0.25 \times 10^{3} \mathrm{CFU} / \mathrm{g}$ of fungi and indicated nonbacterial and fungal pathogens.

\section{ACKNOWLEDGEMENT}

This research was facilitated by the Fundamental Research activities of the Directorate of Research and Community Service, Directorate General of Research and Development, Ministry of Research, Technology, and Higher Education (Kemenristekdikti). The author would like thanks to the Institute for Research and Community Service Universitas Diponegoro for the assignment dated March 20, 2020 Number: 225-67/UN7.6.1/PP/2020.

\section{REFERENCES}

Amanullah, M. M., S. Sekar dan P. Muthukrishnan. 2010. Prospects and potential of poultry manure. Asian Journal of Plant Science. 9:172-182. DOI : https://scialert.net/abstract/?doi=ajps.2010. $\underline{172.182}$

Amrullah, M., B. I. M. Tampoebolon dan B. W. Prasetyono. 2019. Kajian pengaruh proses fermentasi sekam padi amoniasi menggunakan Aspergillus niger terhadap serat kasar, protein kasar, dan total digestible nutrients. Jurnal Pengembangan Penyuluhan Peternakan. 16 (29): 14-24.

Anwar, R., K. Nova dan T. Kurtini. 2014. Pengaruh penggunaan litter sekam, serutan kayu, dan jerami padi terhadap performa broiler di closed house. Jurnal Ilmiah Peternakan Terpadu 2 (3): 115-120.

Dewi, A. K., C. S. Utama dan S. Mukodiningsih. 2014. Kandungan total fungi serta jenis kapang dan khamir pada limbah pabrik pakan yang difermentasi dengan berbagai aras starter. Jurnal Agripet. 14 (2): 102-106.

Wijayanti, E., F. Wahyono dan Surono. 2012. Kecernaan nutrien dan fermentabilitas pakan komplit dengan level ampas tebu yang berbeda secara in vitro. Animal Agricultural Journal 1 (1): 167-179.

Ferdaus, F., M. O. Wijayanti, E. S. Retnonigtyas dan W. Irawati. 2008. Pengaruh ph, konsentrasi substrat, penambahan kalsium karbonat dan waktu fermentasi terhadap perolehan asam laktat dari kulit pisang. Jurnal Widya Teknik 7 (1): 1-14.

Hastuti, D., S. Nur dan B. I. M. Tampubolon. 2011. Pengaruh perlakuan teknologi amofer (amoniasi fermentasi) pada limbah tongkol jagung sebagai alternatif pakan berkualitas ternak ruminansia. Jurnal Mediagro 7 (1): 55-65.

Istiqamah, N., D. Suherman dan B. Zain. 2019. Tingkat kepuasan aspek sosial ekonomi dan lingkungan perusahaan peternakan ayam broiler di Kecamatan Sukaraja Kabupaten Seluma. Jurnal Penelitian Pengelolaan 
Sumberdaya Alam dan Lingkungan 8 (1): 35-47.

Marang, E. A. F., L. D. Mahfudz, T. A. Sarjana, dan S. Setyaningrum. 2018. Kualitas dan kadar amonia litter akibat penambahan sinbiotik dalam ransum ayam broiler. Jurnal Peternakan Indonesia 21 (3): 303 310.

Metasaria, T., D. Septinova dan V. Wanniatie. 2014. Pengaruh berbagai jenis bahan litter terhadap kualitas litter broiler fase finisher di closed house. Jurnal Ilmiah Peternakan Terpadu 2 (3): 23-29.

Mukodiningsih, B., B. Sulistiyanto dan S. S. Sholikhah. 2018. Populasi bakteri dan keberadaan bakteri gram (+) dan (-) dalam pelet calf starter yang ditambah limbah kubis fermentasi. Jurnal Ilmu Nutrisi dan Teknologi Pakan 16 (3): 65-68.

Munira, M. dan A. M. Tasse. 2016. Performans ayam kampung super pada pakan yang disubtitusi dedak padi fermentasi dengan fermentor berbeda. Jurnal Ilmu dan Teknologi Peternakan Tropis 3 (2): 21-29.

Najibulloh, M., N. Ulupi dan Salundik. 2020. Pengaruh daur ulang litter terhadap kualitas litter dan udara dalam pemeliharaan broiler. Livestock and Animal Research. 18 (2): 107-115.

Nasrun, Jalaluddin dan Mahfuddhah. 2015. Pengaruh jumlah ragi dan waktu fermentasi terhadap kadar bioetanol yang dihasilkan dari fermentasi kulit pepaya. Jurnal Teknologi Kimia Unimal. 4 (2): 1-10.

Ningsih, D. R., V. P. Bintoro dan Nurwantoro. 2018. Analisis total padatan terlarut, kadar alkohol, nilai ph dan total asam pada kefir optima dengan penambahan high fructose syrup (hfs). Jurnal Teknologi Pangan 2 (2): 84-88.

Nurdianto, M., C. S. Utama dan S. Mukodiningsih. 2015. Total jamur, jenis kapang dan khamir pellet ayam kampung super dengan penambahan berbagai level pollard berprobiotik. Jurnal Agripet. 15 (1): 79-84.
Pamungkas, W. 2011. Teknologi fermentasi, alternatif solusi dalam upaya pemanfaatan bahan pakan lokal. Jurnal Media Akuakultur 6 (1): 43-48.

Prihandanu, R., A. Trisanto dan Y. Yuniati. 2015. Model sistem kandang ayam closed house otomatis menggunakan omron sysmac CPM1A 20-CDR-A-V1. Jurnal Rekayasa dan Teknologi Elektro 9 (1): 54-62.

Prayitno, S. H., Widiyanto dan C. S. Utama. 2014. Penggunaan ekstrak limbah sayur dalam kombinasi cairan rumen sebagai starter berdasarkan total jamur serta keberadaan kapang dan khamir. Animal Agriculture Journal. 3 (4): 505-510.

Purwono, E. 2018. Pengaruh berbagai macam litterterhadap pertumbuhan ayam broiler. Jurnal Triton 9 (1): 89-95.

Qadarullah, M. N., Munir dan Irmayani. 2018. Analisis nilai ph dan tingkat kerusakan silase pakan komplit yang diformulasi dengan daun lamtoro (Leucaena leucocephala) sebagai pakan ternak ruminasia. Jurnal Bionature 19 (2): 119126.

Rahimi, M. R., Y. A. Alijoo, R. Pirmohammadi dan M. Alimirzaei. 2018. Effects offeeding with broiler litter in pellet-form diet on Qizil fattening lambs' performance, nutrient digestibility, blood metabolites and husbandry economics. Veterinary Research Forum. 9 (3): 245-251. DOI : https://www.researchgate.net/publication/3 28493138

Sariri, A. K. dan Y. W. Harinta. 2018. Pemanfaatan limbah litter broiler untuk pakan ternak ruminansia dan pengelolaan kotorannya. Jurnal Pengamas. 1 (2): 131136.

Utama, C. S., B. Sulistiyanto dan K. N. C. Ginting. 2020. Total jamur dan identifikasi yeast pada limbah kubis fermentasi dengan penambahan vitamin dan mineral. Jurnal Ilmu dan Teknologi Peternakan Tropis 7 (3):196-202.

Utama, C. S., B. Sulistiyanto dan T. B. O. Permata. 2020. Kajian mikrobiologi wheat 
pollard terfermentasi dengan penambahan vitamin dan mineral. Jurnal Peternakan Nusantara 6 (1): 1-6.

Wibowo, A., T. H. Suprayogi dan Sudjatmogo. 2015. Tampilan total plate count Staphylococcus aureus pada susu sapi friesian holstein akibat dipping dengan iodosfor pada berbagai konsentrasi. Animal Agricultural Journal 4 (1): 88- 92.

Wikanastri H., C. S. Utama dan A. Suyanto. 2012. Aplikasi proses fermentasi kulit singkong menggunakan starter asal limbah kubis dan sawi pada pembuatan pakan ternak berpotensi probiotik. Prosiding Seminar Nasional dan Internasional 1 (1): 281-288.
Wulandari, E., B. I. M. Tampoebolon, Widiyanto, dan R. I. Pujaningsih. 2020. Mikrobiologis Salmonella, Water Activity dan Total Bakteri Multinutrien Blok dari Cangkang Kerang dan Cangkang Telur sebagai Sumber Mineral. Jurnal Sain Peternakan Indonesia 15 (1): 43-49.

Yanuartono, A. N., S. Indarjulianto, N. Haribowo, H. Purnamaningsih, S. Rahardjo. 2018. Manure unggas: suplemen pakan alternatif dan dampak terhadap lingkungan. Jurnal Bioteknologi dan Biosains Indonesia 5 (2): 241-257. 